\title{
DIGITAL CHALLENGES TO GEOGRAPHY EDUCATION IN BULGARIA
}

DOI: http://dx.doi.org/10.18509/GBP.2019.78

UDC: 37.016:91(497.2)

378.091.33-028.27:91(497.2)

\section{Georgi Kotseff}

Sofia University “St. Kliment Ohridski”, Faculty of Geology and Geography, Department of Regional Development, Section Didactics of Geography, Bulgaria

\begin{abstract}
The educational system in Bulgaria, as a building block of social development, has always met the challenges it faces. An information society based on knowledge in the context of broad informatization puts specific requirements on education. They are related to the formation of personalities who, confidently in their current times, will be able to fulfill different social roles in the digital age. Modern pupils, as members of this society, have certain needs, which may require a reorganization of some paradigms in geographic education based on the broad application of information technologies and methods of working with them. Geographic education in the context of the global information boom will only achieve its goals if it shows flexibility in conventional forms and learning tools and accepts the challenges of today's new information technology. Research methods: Theoretical analysis, empirical analysis, qualitative and quantitative analysis and evaluation.
\end{abstract}

Keywords: Key words: geography education, digital challenges

\section{INTRODUCTION}

The development of the modern information society implies the penetration of information technologies in all spheres of human activity. The education system, in order to fulfill the public procurement and expectations of this society, can't ignore the development of the pupils' digital culture.

The increasing use of information and communication technologies (ICT) in geography education in the Bulgarian school is dictated by the new trends in didactics and didactics of geography for technology, sociology and humanization of the educational process in teaching the subject. These three trends are an expression of the new philosophy of Bulgarian education, designed in the new normative base. Through their implementation, a new, higher quality of geographic education can be achieved.

In July 2014, a Strategy for Effective Implementation of Information and Communication Technologies in Education and Science of the Republic of Bulgaria (2014-2020) was adopted. The main goal of the Strategy is to provide equal and flexible access to education and scientific information at any time and from anywhere (from a desktop computer, laptop, tablet and mobile phone). Expectations are new technologies in teaching to make less interesting and attractive lessons, motivate pupils and teachers further, which in turn lead to a reduction in the number of dropouts from the education system, to higher achievements in the learning content, to acquiring new useful skills. In the third stage of strategy implementation (long-term), Universality and Sustainability (2018-2020), one of the expected results is formulated as a "transition to electronic textbooks on all subjects". $[1,2]$ 
Undoubtedly, in e-textbooks, there is tremendous potential for the development of education globally. Compared to traditional, electronic textbooks are cheaper, easier to refresh, and do not burden students with heavy backpacks. They imply more interactive, interesting and even personalized training, but this advantage is conditional because it depends entirely on the characteristics and quality of the textbook, as well as on the way it is used in the Bulgarian school.

Until now, experts are unanimous about what the benefits of e-learning textbooks about the quality of education are and the question of whether they are at all still a subject of debate. The results of the study's lead to contradictory conclusions and point to a number of factors influencing the effectiveness of electronic textbooks. Discrepancies in students' personal preferences are found to receive information from paper or digital media, as well as variations in the needs of pupils of different degrees and with different abilities.

Electronic textbooks with the needs of pupils and the skills of pedagogues and other participants in the educational process can only be achieved by carefully introducing them. It is necessary to take into account as many expert opinions as possible, to carry out surveys. This can only happen if there is a well-organized education assessment system. Keeping students' responses, their achievements and difficulties and their motivation to learn is key to achieving good results.

The electronic interactive geography textbook, as an information and methodological resource, performs both classical functions (informative, transformative and systematizing) and contemporary functions (motivating, integrating, coordinating, educating, developing) leading to active learning and teaching in the educational process, enhancing the hereditary approach and the independent cognitive activity of the students. The introduction of this type of resource into the educational practice is a long-term process, subordinate to the global trends and strategic visions for the development of geographic education in Bulgaria.

\section{MATERIALS AND METHODS}

The coming electronic textbooks during the following years are based on the print edition, recreating its content in digital form. They are developed in Portable Document Format (PDF) with a FlippingBook program such as (mozaBook) of Mozaik Education for example. As a new type of information-methodological resource, they offer broad opportunities for organizing interaction in the educational process, enhancing the student's emotional readiness for work, and learning by edutainment. [3, 4, 5]

In the electronic interactive textbook, didactic resources have been developed for each subject, which enrich it in a meaningful way, support the acquisition of the program material, broaden students' knowledge, visualize complex processes and phenomena in geospatial space, provide the opportunity for quality, rapid control and self-control. The icons of the electronic resources are titled, making the teacher and pupils easy to navigate the task type. The teacher has the freedom to choose these resources in work, which are most appropriate according to the local conditions for achieving the objectives and tasks of the lesson.

When working with text in an electronic textbook, the ability to accentuate on some section of content is the use of the zoom function. This is also true for all extra-text components (photos, maps, charts, etc.), questions and tasks at the end of each topic.

Didactical resources in the e-textbook can be grouped into three groups:

- Interactive test tasks (exercises). The variety of didactical resource variants here is the largest. Content is designed in accordance with the purpose of the lesson, the 
characteristics of the content and the age of the students. Tasks can be differentiated into several types: tasks with one true answer; multiple response tasks; tasks type correct / wrong; compliance tasks; to fill in a skipped text or word; for stacking; to search for text errors; crossword puzzles completed using the keyboard; to connect a puzzle type; to locate a geographic location, etc. When working with the test tasks, a suitable software solution is to build a panel that gives information about the results obtained when working with the resource - the number of correct, wrong and missing answers, as well as percentage results. Ability to edit responses after receiving an evaluation. Automatic reordering of responses after "closing" the resource to avoid remembering the position of correct answer by students when the resource is reopened; $[3,4,5]$

- Interactive tasks (exercises) and slide show visualizations (slideshows). These didactic resources foster the mediation in the educational process through methodologically selected high quality photo material and graphic images. The introduction of tasks into the resource assists in the easy and lasting learning of the content. In most cases, resources are sounded, giving them even more appeal; [3, 4, 5]

- 3D animations (3D models) in the e-textbook visualize complex scenic processes and objects, production activities, cultural sights, etc. at high graphical level. For the geography education with a view to developing cartographic culture of students, the resources of the resource are valuable for presenting interactive maps with dynamic content. Some of the resources include games and tests to help understand and absorb the nature of the processes and phenomena that have been demonstrated. The resource enables the teacher to work with an interactive interface to select content, remove unnecessary information, work with auxiliary text, include a background music, rotate the patterns. $[3,4,5]$

Because of the possibility of interactive presentation of the course material, electronic textbooks can be used in lessons for different purposes: to clarify the new teaching material, to summarize, exercise, systemize, consolidate for control. Using this new type of information and methodological resource can easily and accurately focus on the most important of the learning material, quickly fill gaps, form knowledge, skills, competencies and relationships.

"When discussing the benefits of electronic textbooks, at least the following things should be considered, namely:

- the size of textbooks - often textbooks are heavy, and given that students have to wear at least a few daily, this problem becomes essential, and electronic textbooks are "stacked" in a laptop, electronic reader or other mobile device ;

- finding specific information in textbooks - much of today's electronic textbooks offer search features, making searching for specific information faster and easier than paper variants;

- working with text and text - electronic textbooks are easily highlighted, text is copied and transferred to another file, information is processed, unlike the "notes" on the paper version;

- updating of information - e-textbooks offer faster, timely and cheap updating of learning, compared to paper textbooks;

- interaction in presentation of information - some electronic textbooks are available simulations, audio and video files, hyperlinks, etc. 
- textbook cost - Electronic textbooks can be much cheaper than buying new textbooks in a paper version." [6]

Along with all the advantages, some disadvantages should not be overlooked.

The creation of electronic textbooks is sometimes not in the power of a teacher. Therefore, they need to be developed by specialists with the necessary pedagogical, methodological and technological knowledge, skills and competencies.

Not all schools in Bulgaria have the opportunity to purchase the costly technique for demonstrating electronic textbooks such as interactive boards, multimedia projectors, and other personal digital devices.

Electronic textbooks should not replace traditional training with paper versions. Therefore, it is necessary to achieve a precise methodical balance.

"In general, electronic textbooks must meet the following requirements:

- be consistent with the modern concept of multimodal presentation of the curriculum;

- have easy and intuitive navigation within the textbook;

- have a variety of resources - a part of the resources (such as a task sheet) the teacher can use both in the course of the skill lesson and a summary of knowledge at the end of the class (they complement the set of tasks included in the teaching aids of a given subject);

- provide interactivity in class between the teacher, pupils and the learning content (thus assigning an active role to the learner in the process of forming specific subject knowledge and skills);

- depending on the software and formats used, images (including picture galleries), video, audio files and interactive animated models, as well as web pages, etc., are built in;

- include videos, interactive simulations to help illustrate complex processes and phenomena that can't otherwise be mastered." [6]

\section{RESULTS AND DISCUSSION}

Interactive boards are an example of the rapid penetration of innovative technologies and software inventions into the geographic education system. Their use aims to change the quality of the subject's education as a result of the expectations of teachers and pupils. The board can be written, painted to make changes to the content of the lesson, to work in the Internet environment, to print, to store information, etc. It should be borne in mind that the interactive board is only one part of a complete system for presenting information without a suitable pre-prepared multimedia product, it can't develop all its functionalities. It is the demonstration of electronic textbooks with interactive boards aimed at enhancing the quality of the educational process in geography in the modern Bulgarian school. Still their high cost is a difficulty in buying them. In the school year 2018 - 2019 the electronic interactive textbook of Geography, initiated by the Ministry of Education and Science, are now available for free and can be found on the relevant platforms on the Internet for all classes and subjects. This is a positive step towards the introduction and validation of electronic textbooks in the system of geographic education in Bulgaria.

"Taking advantage of the new toolkit and rethinking teaching theories, it is now time to use 'electronic dependence' to improve 'educational productivity' " [7].

New technologies "enable the learning process to be organized in a way that is maximally geared to individual learners' needs while building digital competences. The technical means used to provide teaching materials should be constructed according to contemporary pedagogical theories." [8]. 
The Electronic Interactive Textbook is a modern multimedia product containing a rich variety of didactical resources developed at a high technologically and methodologically substantiated content level. It does not replace the printed edition [9, 10], but is an information and methodological resource that accompanies it in response to the needs of the modern teacher and pupil living in the conditions of the information society.

\section{REFERENCES}

[1] Йтовска К., А. Асенова. Изследване на нагласите към електронните учебници сред ученици от 8-12 клас в системата на училищното образование в България. Научни трудове Русенски университет, том. 45, серия 11, 2015, с. 115-119

[2] Стратегия за ефективно прилагане на информационни и комуникационни технологии в образованието и науката на Република България (2014-2020г.), 2014.

[3] Цанкова, Л., Е. Лазарова, Н. Гетова, Г. Коцев. География и икономика 5. клас. Книга за учителя, "Просвета Плюс" София, 2016, 21-23

[4] Цанкова, Л., Н. Димов, Е. Лазарова, Г. Коцев, Г. Бърдаров, Н. Гетова Електронен учебник География и икономика 5. клас "Просвета Плюс" София, 2016

[5] Цанкова, Л., Е. Лазарова, Г. Коцев, Г. Бърдаров, Н. Гетова Електронен учебник География и икономика 6. клас “Просвета Плюс", София, 2017

[6] Асенова А., К. Йотовска. Електронните учебници в системата на училищното образование в България - реалности и перспективи, Списание на Софийския университет за образователни изследвания, 2014, 433

[7] Налбантова, В. Втори форум на българските училища в западното полукълбо. Мястото на онлайн обучението днес. Пьтища за успешно преподаване във виртуална среда. 2016, Достьпно на: http://www.abgschool.org/drupal/?q=node/368 (14.04.19)

[8] Терзиева, В. П., Кадемова-Кацарова. Съвременни ИКТ базирани методи за обучение, VI-та Национална конференция. Образованието в информационното общество 2016, p. 237-247, Достьпно на: http://scigems.math.bas.bg:8080/jspui/bitstream/10525/2334/1/EIS2013-book-p24.pdf (14.04.19)

[9] Цанкова, Л., Н. Димов, Е. Лазарова, Г. Коцев, Г. Бърдаров, Н. Гетова География и икономика 5. клас "Просвета Плюс" София, 2016

[10] Цанкова, Л., Е. Лазарова, Г. Коцев, Г. Бърдаров, Н. Гетова География и икономика 6. клас “Просвета Плюс", София, 2017 